carcinogenic activity. It may be that oxidation of the nitrogen enhances the ease of hydrolysis, as suggested by Irving (1966), thereby allowing release of the $N$-hydroxylated carcinogen. Acetylation of an aromatic amine usually directs ring hydroxylation away from the ortho-position to give rise to inactive metabolites. It is therefore surprising to find such a high rate of hydrolysis associated with the isomers having the lower toxicity.

This work was carried out while the author was a Research Fellow of The Royal Commission for the Exhibition of 1851.

Booth, J. \& Boyland, E. (1964). Biochem. J. 91, 362. Clayson, D. B. (1962). Chemical Carcinogenesis. London: J. and A. Churchill Ltd.

Gorrod, J. W. (1968). Tetrahedron Lett. no. 59, p. 6155. Gorrod, J. W. \& Carey, M. J. (1970). Biochem.J.119, 52 P. Irving, C. C. (1966). Cancer Res. 26, 1390.

Poirier, L. A., Miller, J. A. \& Miller, E. C. (1963). Cancer Res. 23, 790.

Weisburger, J. H. \& Weisburger, E. K. (1966). Chem. Engng News, 43, 124.

\section{A New Form of $\boldsymbol{N}$-Acetyl- $\beta$-glucosaminidase Present in Pregnancy Serum}

By J. L. Stirling. (Department of Biochemistry, Queen Elizabeth College, Campden Hill, London W.8, U.K.)

$N$-Acetyl- $\beta$-glucosaminidase activity in human serum has been shown to increase during pregnancy (Walker, Woollen \& Pugh, 1960). By histochemical investigation they showed that there were high $N$-acetyl- $\beta$-glucosaminidase activities in the decidual cells and the chorion, and they suggested that these sites might be the origin of the elevated serum activity.

Two main forms of $N$-acetyl- $\beta$-hexosaminidase (A and B) are known to exist in human tissues and these can be differentiated by starch-gel electrophoresis (Robinson \& Stirling, 1968; Okada \& O'Brien, 1969). Serum shows only $N$-acetyl- $\beta$ glucosaminidase $A$ when examined in this way, but when sera collected at various stages of pregnancy (1 month to full term) are examined two electrophoretically distinct forms can be seen. The elevation of total activity is due to an increased amount of form $A$ and to the appearance of a new species of enzyme designated $N$-acetyl- $\beta$-glucosaminidase $P$. This pregnancy form of the enzyme has a slow anodic mobility in electrophoresis at $\mathrm{pH} 7.0$ and can be distinguished from $N$-acetyl- $\beta$ glucosaminidase $\mathrm{A}$, which migrates rapidly towards the anode. It can also be distinguished from form $B$, found in tissues, which moves towards the cathode.

$N$-Acetyl- $\beta$-glucosaminidases $\mathbf{A}$ and $\mathbf{P}$ can be separated by DEAE-cellulose chromatography at pH7.0 in $10 \mathrm{~mm}$-sodium phosphate buffer by application of a sodium chloride gradient, peak $P$ appearing at a salt concentration of $0.12 \mathrm{M}$ and peak $A$ at $0.19 \mathrm{M}$. There was no separation of $A$ and $P$ activities on gel filtration through Sephadex G-200.

The thermal stability of enzyme $P$ is intermediate between that of form $A$, which is rapidly denatured at $\mathrm{pH} 5.0$ and $50^{\circ} \mathrm{C}$, and that of form $\mathrm{B}$, which is almost completely stable under these conditions. $K_{m}$ values for $N$-acetyl- $\beta$-glucosaminidases $A$ and $P$ were 0.65 and $0.55 \mathrm{~mm}$ respectively, but both had optimum pH4.5 in $0.1 \mathrm{M}$-sodium citrate buffer. $N$-Acetyl- $\beta$-glucosaminidases $A$ and $P$ could not be distinguished by inhibition due to acetate, $N$-acetylgalactosamine or $p$-chloromercuribenzoate, and both were unaffected by dithiothreitol and $N$-ethylmaleimide.

When extracts of placenta and foetal membranes were investigated by starch-gel electrophoresis and DEAE-cellulose chromatography both tissues had A and B activities but only a trace of $P$ activity, which was possibly contributed by the maternal blood in the organ. All the $N$-acetyl- $\beta$-glucosaminidase in cord serum at birth is of the A type.

This work was carried out at Makerere University, Uganda, and supported by a grant from the Publications and Research Grants Committee.

Okada, S. \& O'Brien, J. S. (1969). Science, N.Y., 165, 698. Robinson, D. \& Stirling, J. L. (1968). Biochem. J. 107, 321.

Walker, P. G., Woollen, M. E. \& Pugh, D. (1960). J. clin. Path. 13, 353.

\section{Activation of Coagulation Factor $X$ by Insoluble Trypsin}

By R. M. Howell and R. J. Dupe. (Department of Biochemistry, Queen Elizabeth College, Campden Hill, London W.8, U.K.)

Factor $\mathrm{X}$ occupies an important position in the final stage of coagulation leading to the activation of prothrombin. The parent zymogen (Factor $\mathrm{X}$ ) is converted into the active form (Factor $\mathrm{Xa}$ ) by agents that precede it in the clotting sequence, and additionally by trypsin (Hanahan \& Papahadjopoulos, 1965) and a component of Russell's-viper venom (Williams \& Esnouf, 1962).

The present work is a continuation of an investigation on clot production in vivo in which nonproteolytic activation of Factor $X$ was examined with various surface-active agents (Howell \& Scott, 1967). For comparison a reliable protease activator is required, but prolonged contact with soluble trypsin leads to rapid loss of clotting activity because proteolysis cannot be terminated. Russell's-viper venom is unsuitable as an activator for systems 